\title{
OPTIMALISASI ASPEK TEKNIS PADA PERANCANGAN BISNIS VIRGIN COCONUT OIL (VCO)
}

\author{
Zakka Ugih Rizqi ${ }^{1}$, Adinda Khairunisa ${ }^{2}$, Riska Iva Riana ${ }^{2}$ \\ ${ }^{1}$ National Taiwan University of Science and Technology, Taipei, Taiwan \\ ${ }^{2}$ Universitas Islam Indonesia, Yogyakarta, Indonesia \\ ugihzakka@gmail.com
}

\begin{abstract}
Abstrak: Desa Rejosari adalah salah satu Desa di Kabupaten Purworejo, Jawa Tengah yang memiliki potensi sumber daya alam (SDA) berupa pohon kelapa. Akan tetapi, pemanfaatan yang tidak maksimal sering mengakibatkan pembuangan kelapa disebabkan jumlah panen yang berlebih. Untuk mengoptimalkan pemanfaatan SDA tersebut, dilakukan perancangan bisnis produksi Virgin Coconut Oil (VCO). Pengabdian ini fokus pada aspek teknis yang meliputi pemilihan lokasi produksi dengan metode Analytical Hierarchy Process (AHP), analisis aliran produksi VCO, layout design, dan penentuan jumlah pekerja dan peralatan yang optimal berbasis simulasi. Hasil pemilihan lokasi produksi pada program pengabdian ini menunjukkan bahwa lokasi yang terletak di samping SMK VIP Maarif NU 1 Kemiri merupakan lokasi yang paling optimal dilihat dari kriteria kemudahan akses, luas bangunan, dan ketersediaan sarana dan prasarana. Kemudian untuk memenuhi permintaan selama 4 bulan ke depan, diperlukan 13 orang pekerja beserta peralatan yang mendukung proses produksi dengan investasi serendah mungkin. Selanjutnya layout dari lantai produksi VCO dirancang dengan pertimbangan dapat menghasilkan jarak seminimal mungkin sehingga mampu meningkatkan efisiensi serta mempermudah jalan keluar-masuk barang. Hasil analisis teknis kemudian disimulasikan menggunakan software Flexsim versi 2021 dan menunjukkan bahwa perancangan bisnis VCO telah mencapai hasil efektif dilihat dari ketercapaian output produksi dan efisien dilihat dari utilisasi pekerja. Uji coba produksi serta penyuluhan telah dilakukan sebagai bukti validasi.
\end{abstract}

Kata Kunci: Analytical Hierarchy Process (AHP), perancangan bisnis, simulasi, Virgin Coconut Oil (VCO)

\begin{abstract}
Rejosari Village is one of the villages in Purworejo Regency, Central Java, which has natural resource potential (SDA) in the form of coconut trees. However, the disposal of coconuts due to the excessive harvest and lack of utilization often happens. A Virgin Coconut Oil (VCO) production business was designed to optimize the utility of natural resources. This community service focuses on technical aspects analysis including the selection of production location using the Analytical Hierarchy Process (AHP) method, VCO production flow analysis, layout design, and the determination of the optimal number of workers and equipment based on simulation. The result of the production location selection indicates that the location next to the Vocational High School Maarif NU 1 Kemiri is the most optimal location seen from the criteria of easy access, building area, and availability of facilities and infrastructure. Then to meet the demand for the next 4 months, it requires 13 workers along with equipment that supports the production process with the lowest possible investment. Furthermore, the layout of the VCO production floor was designed with the consideration that it could produce a minimum distance to increase efficiency and facilitate the passage of goods in and out. The results of the technical analysis were then simulated using the Flexsim software and showed that the vCO business design has achieved effectiveness examined from the achievement of production output and efficiency from optimum workers utilization. Production trials and socialization were carried out as a validation evidence.
\end{abstract}

Keywords: Analytical Hierarchy Process (AHP), business design, simulation, Virgin Coconut Oil (VCO) 


\section{Pendahuluan}

Sumber Daya Alam (SDA) merupakan suatu kekayaan yang berasal dari alam dan akan menjadi nilai tambah jika diolah dengan baik. Desa Rejosari merupakan salah satu desa yang ada di Purworejo, Jawa Tengah, Indonesia dan memiliki potensi sumber daya alam yang sangat baik. Akan tetapi, kesadaran masyarakat untuk mengembangkan potensi tersebut masih sangat rendah. Mayoritas penduduk Desa Rejosari memiliki profesi sebagai petani dimana hasil kerjanya belum tercapai produktivitas yang tinggi karena keterbatasan pengetahuan dan modal yang dimiliki.

Dalam hal sumber daya kelapa, Desa Rejosari memiliki potensi yang sangat menjanjikan dimana hampir setiap rumah memiliki pohon kelapa yang tumbuh subur. Kurangnya kesadaran untuk memanfaatkan potensi kelapa dan modal usaha sekaligus kurangnya pengetahuan dalam proses produksi khususnya VCO, menjadikan banyak buah kelapa yang terbuang sia-sia ketika masa panen tiba. Untuk memanfaatkan potensi tersebut dan dengan mempertimbangkan keterbatasan modal desa, buah kelapa tersebut dapat diproduksi menjadi minyak kelapa murni atau Virgin Coconut Oil (VCO) yang bernilai tambah sehingga pada akhirnya akan menambah pendapatan bagi Desa Rejosari.

VCO merupakan produk olahan dari daging kelapa yang berupa cairan berwarna jernih, tidak berasa, dengan bau khas kelapa (Aziz, Olga, \& Sari, 2017). Pembuatan VCO juga tidak membutuhkan biaya yang mahal karena bahan baku sudah tersedia di Desa Rejosari dan pengolahannya yang sederhana. Saat ini, metode pembuatan VCO beraneka macam yaitu dengan teknik pemanasan, pemancingan minyak, dan sentrifugasi (Anwar \& Salima, 2016).

Penjualan VCO diperkirakan memiliki peluang yang besar. Hal ini sesuai dengan berbagai manfaat dari VCO itu sendiri yaitu dapat mengatasi beberapa jenis penyakit antara lain penyempitan pembuluh darah, sariawan, batuk, pilek, hepatitis, diabetes, asam urat, kolesterol tinggi, kram-kram, pengapuran, maag, nyeri di lutut, jantung, kurap, keputihan, ambeien, amandel, kelebihan berat badan dan Human Immunodeficiency Virus (HIV) (Barlina \& Torar, 2008). Oleh karena itu, penjualan produk VCO memiliki potensi pasar yang baik bagi masyarakat Indonesia khususnya daerah Jawa Tengah yang bisa dimanfaatkan Desa Rejosari untuk mendapatkan profit sebesar-besarnya dengan memanfaatkan sumber daya kelapa yang ada.

Perancangan bisnis yang baik memerlukan suatu analisis perencanaan yang mendalam. Tanpa adanya perencanaan bisnis yang baik, maka bisnis sangat berpotensi mengalami kerugian besar. Dalam konteks studi kelayakan bisnis, aspek teknis dan teknologis memainkan peranan penting dalam melakukan perancangan bisnis (Umar, 2003; Mohammed, Naji, \& Ali 2019). Khususnya untuk melihat seberapa besar kapasitas yang diperlukan untuk memenuhi permintaan yang ada hingga memilih lokasi serta proses produksi yang tepat.

Studi literatur dilakukan untuk melihat pengabdian sejenis terkait perancangan bisnis khususnya pada aspek teknis. Beberapa diantaranya dilakukan oleh Kuncoro, Naryoto, \& Nugroho (2017), Bangkele, Antara, \& Damayanti (2016), dan Elquliti \& Elalem (2018) pada bisnis makanan, serta Tarigan, et al. (2019) dan Saepudin, Putra, \& Adrian (2019) pada bisnis jasa. 
Penelitian maupun pengabdian masyarakat sebelumnya yang berkaitan dengan VCO hanya fokus pada pengembangan model bisnis melalui Business Model Canvas (BMC) (Wulandary, et al., 2020). Selain itu, motivasi terdahulu dalam membangun bisnis VCO hanya fokus kepada pencarian keuntungan finansial dan pemasaran tanpa memperhatikan keterbatasan modal (Rahman, Palenewen, \& Elly, 2016; Jurnalis, 2019). Belum ditemukan penelitian maupun pengabdian masyarakat yang fokus pada analisis dan optimalisasi aspek teknis dalam perancangan bisnis VCO. Motivasi muncul dari kurangnya pemanfaatan SDA dan masyarakat sekitarnya yang nanti akan dipekerjakan sebagai pekerja di bisnis tersebut sehingga tidak hanya berefek pada aspek finansial saja, melainkan juga aspek sosial bahkan lingkungan karena pembuangan kelapa yang tidak diolah bisa menyebabkan waste di lingkungan sekitar desa. Di lihat dari sisi sustainability, bisnis ini sangat mendukung konsep keberlanjutan karena memiliki semua aspek dalam Triple Botom Line (Arowoshegbe \& Emmanuel, 2016).

Pengabdian ini tidak hanya berkontribusi kepada masyarakat Rejosari saja, tetapi dari sisi penelitian, metode simulasi diskrit digunakan untuk memvalidasi dan mengoptimalkan perancangan bisnis pada aspek teknis yang belum ditemukan dari penelitian sebelumnya. Pada bagian berikutnya, dijelaskan mengenai metode pengambilan maupun pengolahan data, hasil dan pembahasan yang meliputi pemilihan lokasi produksi dengan metode AHP, penentuan aliran produksi VCO, layout design, penentuan jumlah pekerja dan peralatan yang optimal, simulasi lantai produksi, hingga penyuluhan kepada warga desa, dan diakhiri dengan kesimpulan.

\section{Metode}

Bagian metode terbagi menjadi dua bagian yaitu metode pengambilan data dan metode pengolahan data. Penjelasan terkait keduanya dipaparkan sebagaimana berikut ini.

\section{Metode pengambilan data}

Pengambilan data dilakukan dengan beberapa cara. Untuk menentukan lokasi produksi VCO, data diperoleh melalui diskusi dengan warga Desa Rejosari untuk menentukan alternatif dan kriteria pemilihan. Kuesioner perbandingan berpasangan kemudian digunakan untuk menentukan alternatif terbaik. Menurut Saaty (1980), skala 1 sampai 9 adalah skala terbaik dalam mengekspresikan pendapat sehingga digunakan dalam penelitian ini. Penilaian diberikan kepada single expert yaitu ketua Badan Permusyawaratan Desa (BPD) Rejosari yang mengerti mengenai lingkungan Desa Rejosari.

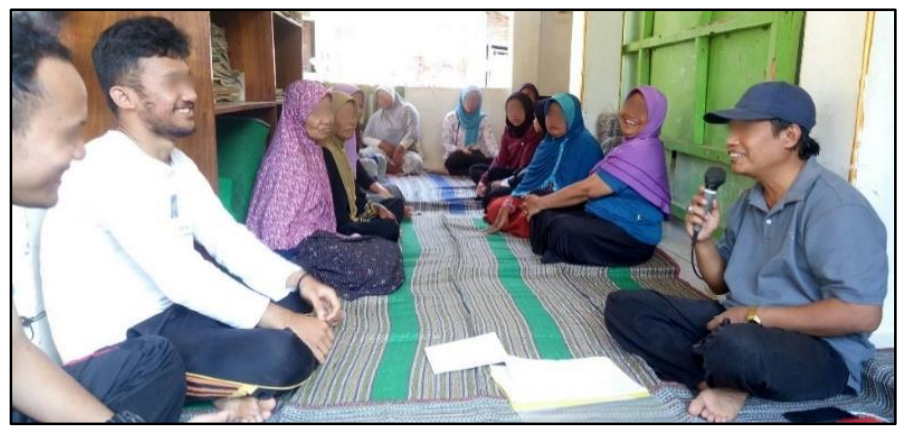

Gambar 1. Diskusi dengan warga Desa Rejosari 
Untuk menentukan proses produksi VCO yang diperlukan, dilakukan wawancara terhadap mahasiswa Teknik Kimia Universitas Islam Indonesia yang mengetahui proses teknis kimiawi di lantai produksi sekaligus sebagai bentuk kerjasama dalam pengabdian masyarakat di Desa Rejosari, Purworejo, Jawa Tengah, Indonesia.

\section{Metode pengolahan data}

\section{Analytical Hierarchy Process (AHP)}

Dalam menentukan lokasi produk VCO yang tepat di wilayah Desa Rejosari, digunakan metode AHP sebagai pendukung pengambilan keputusan. AHP adalah suatu teknik pengambilan keputusan yang dikembangkan untuk kasus-kasus yang memiliki berbagai hirarki analisis (Saaty, 1980). Metode ini merupakan cara praktis untuk menangani permasalahan kompleks secara kuantitatif. Metode ini menggunakan pembandingan secara berpasangan, menghitung faktor pembobot, dan menganalisisnya untuk menghasilkan prioritas relatif di antara alternatif yang ada (Herjanto, 2009). Kemudian konsistensi perbandingan berpasangan dilihat berdasarkan rasio konsistensi yang merupakan pembagian antara indeks konsistensi dan indeks random konsistensi. Jika rasio konsistensi $\leq 0,1$, hasil perhitungan data dapat dibenarkan.

\section{Penentuan Kapasitas Produksi}

Penentuan besarnya kapasitas produksi yang dibutuhkan menggunakan persamaan di bawah ini. Selanjutnya persamaan ini disebut dengan persamaan 1.

$$
\text { Kebutuhan }=\frac{\text { waktu } \times \text { target valume penjualan bulan depan }}{\text { jam kerja efektif dalam satu bulan (menit) }}
$$

Untuk menentukan kapasitas produksi, perlu diketahui terlebih dahulu mengenai proses produksi yang diperlukan untuk menghasilkan VCO. Di antara berbagai macam metode pembuatan VCO, dipilih metode sentrifugasi karena metode tersebut tidak menggunakan alatalat atau bahan yang membutuhkan modal besar dimana hanya cukup dengan didiamkan hingga minyak kelapa dan air terpisah dengan cara memutuskan ikatan lemak dan protein pada daging kelapa. Berikut adalah urutan kegiatan untuk memproduksi VCO.

1. Bahan dasar yang dipakai adalah daging buah kelapa masak yang berumur 10-12 bulan. Kelapa tua tersebut kemudian dikupas yang membutuhkan waktu selama 1,5 menit.

2. Daging buah yang didapat lalu diparut secara manual yang membutuhkan waktu 3 menit.

3. Daging hasil parutan kemudian ditambahkan air dan diperas hingga menghasilkan santan yang membutuhkan waktu 2 menit.

4. Setelah diperoleh santan kemudian didiamkan selama 1 jam sehingga terpisah menjadi 2 lapisan, yaitu air (di bawah) dan krim (di atas). Santan disimpan pada wadah/ember titrasi dimana 1 ember dapat menyimpan santan yang dihasilkan dari 10 daging buah kelapa.

5. Kemudian dipisahkan air dan krimnya dimana air dibuang dan krim yang dilanjutkan dalam proses produksi dimana membutuhkan waktu 0,5 menit.

6. Krim didiamkan selama 24 jam sehingga krim tadi akan terpisah menjadi 3 bagian: yang pertama adalah minyak VCO yang berada pada lapisan teratas, yang kedua adalah blondo 
pada lapisan tengah, dan yang ketiga adalah air yang ada di lapisan terbawah.

7. Selanjutnya dipisahkan kembali minyak VCO diambil yang membutuhkan waktu selama 1 menit.

8. Minyak yang diperoleh kemudian dikemas dalam botol sebesar $60 \mathrm{ml}$ yang membutuhkan waktu selama 1 menit.

\section{Simulasi proses produksi}

Perencanaan bisnis pada dasarnya bisa dilakukan dengan mengasumsikan sistem bersifat deterministik. Akan tetapi, pada kenyataanya banyak kejadian yang sifatnya tidak pasti khususnya pada lantai produksi yang masih mengutamakan tenaga manusia dan belum menggunakan mesin berteknologi tinggi. Untuk mengatasi hal tersebut simulasi sistem produksi merupakan cara yang tepat untuk mengoptimalkan pengambilan keputusan.

Tipe simulasi yang digunakan yaitu Discrete-Event Simulation (DES) dengan bantuan software Flexsim versi 2021. Flexsim dipilih karena mampu memvisualisasikan sistem dengan sangat baik dan dapat disimulasikan secara bersamaan. Dalam perencanaan bisnis, hal ini menjadi penting diketahui terutama dalam fase planning di mana semua stakeholder diharapkan memahami konsep perencanaannya dan dengan visualisasi yang baik, maka akan mempermudah proses pemahaman.

Dengan dilakukannya simulasi, perkiraan output produksi menjadi lebih nyata dan sangat membantu dalam proses pengambilan keputusan terutama dalam menentukan jumlah pekerja, peralatan, dan desain layout produksi. Waktu proses produksi diasumsikan berdistribusi uniform dengan batas minimum dan maksimumnya adalah $\pm 20 \%$ dari waktu perkiraan expert. Simulasi dilakukan sebanyak 30 replikasi untuk memberikan hasil estimasi yang representatif.

\section{Hasil dan Pembahasan}

\section{Penentuan lokasi produksi}

Dalam proses penentuan lokasi produksi VCO, diperoleh 3 alternatif lokasi dengan 3 kriteria penilaian yang dapat dilihat pada Tabel 1 . Alternatif lokasi produksi VCO dapat dilihat pada Gambar 2.

Tabel 1. Alternatif Lokasi dan Kriteria Penilaian

\begin{tabular}{ll}
\multicolumn{1}{c}{ Alternatif Lokasi } & \multicolumn{1}{c}{ Kriteria Penilaian } \\
\hline (A) Di dekat Posko 180 & 1. Kemudahan akses \\
\hline (B) Di sisi jalan RT 1 RW 01 & 2. Luas bangunan \\
\hline (C) Di samping SMK VIP Maarif NU 1 Kemiri & 3. Ketersediaan sarana dan prasarana \\
\hline
\end{tabular}

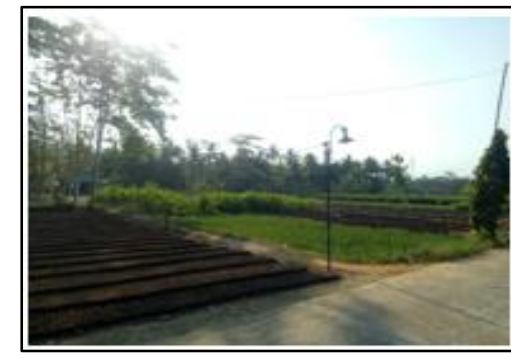

(A)

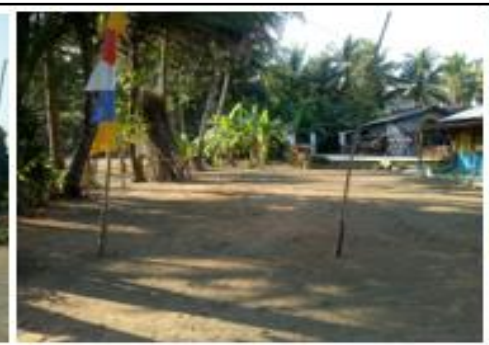

(B)

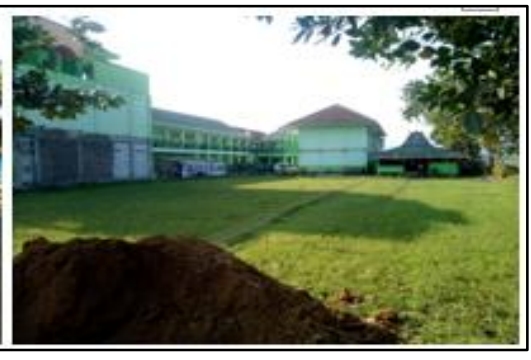

(C)

Gambar 2. Alternatif lokasi produksi VCO 
Hasil pemilihan lokasi produksi VCO menggunakan AHP dilakukan dengan membandingkan antar kriteria, membandingkan alternatif terhadap kriteria 1, membandingkan alternatif terhadap kriteria 2, dan membandingkan alternatif terhadap kriteria 3 yang hasilnya dapat dilihat pada Tabel 2.

Tabel 2. Hasil Perhitungan AHP

\begin{tabular}{ccccc}
\hline \multirow{2}{*}{$\begin{array}{c}\text { Bobot } \\
\text { Alternatif }\end{array}$} & $\begin{array}{c}\text { Kemudahan } \\
\text { Akses }\end{array}$ & $\begin{array}{c}\text { Luas } \\
\text { Bangunan }\end{array}$ & $\begin{array}{c}\text { Ketersediaan Sarana dan } \\
\text { Prasarana }\end{array}$ & Bobot \\
\hline & 0,7235 & 0,1932 & 0,0833 & \\
\hline A & 0,1925 & 0,6651 & 0,7014 & 0,326 \\
\hline B & 0,1307 & 0,1038 & 0,2132 & 0,132 \\
\hline C & 0,6768 & 0,2311 & 0,0853 & 0,541 \\
\hline
\end{tabular}

Hasil perhitungan di atas telah dilakukan uji konsistensi di mana rasio konsistensinya < 0,1 sehingga hasilnya valid dan dapat dianalisis lebih jauh. Berdasarkan hasil perhitungan diketahui lokasi yang memiliki potensi baik untuk dibangun tempat produksi VCO adalah di samping SMK VIP Maarif NU 1 Kemiri (C). Dengan adanya hasil ini maka pembangunan lokasi produksi nanti tidak mengalami masalah serta sesuai dengan apa yang diharapkan terutama dinilai dari 3 kriteria, yaitu mudah diakses, luas bangunan sesuai dengan yang dibutuhkan dan tersedia sarana dan prasarana.

\section{Hasil penentuan kapasitas produksi}

Setelah ditentukan rencana pembangunan lokasi produksi yang tepat untuk produksi VCO, berikutnya adalah perencanaan kapasitas produksi VCO yang diperlukan untuk memenuhi semua permintaan kedepannya. Gambar 3 merupakan model input-process-output yang dibutuhkan untuk menghasilkan VCO.

\begin{tabular}{|c|c|c|}
\hline Input & Process & Output \\
\hline $\begin{array}{l}\text {-Kelapa Tua } \\
\text {-Air } \\
\text {-Wadah/Ember/Botol } \\
\text {-Pemarut/Mesin Parut } \\
\text {-Pengupas Kelapa }\end{array}$ & $\begin{array}{l}\text {-Pengupasan kelapa } \\
\text {-Pemarutan } \\
\text {-Pemerasan } \\
\text {-Pengendapan } \\
\text {-Pengemasan }\end{array}$ & $\begin{array}{l}\text { Virgin Coconut } \\
\text { Oil (VCO) }\end{array}$ \\
\hline
\end{tabular}

Gambar 3. Model Input-Process-Output

Menurut Abidanish (2010), 1 liter VCO dapat diperoleh dari 10 buah kelapa tua. Sehingga 1 buah kelapa tua menghasilkan 0,1 liter VCO. Rencana penjualan VCO adalah sebesar 60 mililiter per produk. Jika dikalkulasikan, 1 buah kelapa tua dapat menghasilkan sebesar 1,6 produk kemasan VCO. Proses produksi VCO beserta waktu siklusnya ditunjukkan pada Tabel 3.

Dikarenakan perencanaan ini adalah rencana pembangunan bisnis baru, target penjualan ditentukan dari subjektivitas pemilik bisnis dengan mempertimbangkan kebutuhan-kebutuhan masyarakat terhadap VCO yang tinggal di sekitar Purworejo, Jawa Tengah beserta wawancara terhadap penjual VCO yang telah ada sebelumnya. Dalam hal ini, ditargetkan penjualan pada 
bulan ke-1 produksi adalah sebanyak 3000 unit, bulan ke-2 3200 unit, bulan ke-3 3400 unit, dan bulan ke-4 3500 unit. Jika dalam 1 bulan diasumsikan waktu kerja adalah selama 25 hari dan jam kerja efektif adalah selama 7 jam, maka hasil perhitungan kapasitas produksi untuk setiap proses dengan menggunakan persamaan 1 ditunjukkan pada Tabel 4. Dari perkiraan jumlah kapasitas tersebut, maka jumlah kebutuhan peralatan/mesin/pekerja pada ditunjukkan pada Tabel 5.

Tabel 3. Ringkasan proses produksi VCO

\begin{tabular}{ccc}
\hline Kode & Proses & Waktu Proses (Menit) \\
\hline A & Pengupasan kelapa & 1,5 \\
\hline B & Pemarutan & 3 \\
\hline C & Penambahan air dan Pemerasan & 2 \\
\hline D & Pengendapan 1 dan Pemisahan 1+ Pengendapan 2 dan & 144,75 \\
\hline E & pemisahan 2 & 1 \\
\hline
\end{tabular}

Tabel 4. Hasil perhitungan kapasitas tiap proses

\begin{tabular}{ccc}
\hline Proses & Perhitungan & Hasil (Unit/Bulan) \\
\hline A & $2940 / 1,5$ & 1960 \\
\hline B & $2940 / 3$ & 980 \\
\hline C & $2940 / 2$ & 1470 \\
\hline D & $2940 / 144,75$ & 20,3 \\
\hline E & $2940 / 1$ & 2940 \\
\hline
\end{tabular}

Tabel 5. Jumlah kebutuhan peralatan

\begin{tabular}{cccccc}
\hline Bulan & A & B & C & D & E \\
\hline 1 & 1,531 & 3,06 & 2,04 & 147,78 & 1,02 \\
\hline 2 & 1,633 & 3,271 & 2,18 & 157,64 & 1,09 \\
\hline 3 & 1,735 & 3,47 & 2,31 & 167,49 & 1,17 \\
\hline 4 & 1,786 & 3,57 & 2,38 & 172,41 & 1,19 \\
\hline
\end{tabular}

Berdasarkan hasil perhitungan, proses A membutuhkan jumlah pekerja sekaligus alat yang diperlukan adalah 1,5 yang dibulatkan ke atas sehingga diperlukan 2 orang pekerja dan 2 alat pengupas kelapa (golok), proses $B$ membutuhan 4 pekerja dan 4 alat pemarut, proses $C$ membutuhkan 3 pekerja dan 3 alat peras (kain saring tahu), proses D membutuhkan 148 ember titrasi di bulan pertama, 158 di bulan kedua, 168 di bulan ketiga dan 173 di bulan keempat. Akan tetapi, pekerja hanya dibutuhkan 2 orang (perhitungan sama dengan proses A) karena proses $\mathrm{D}$ merupakan proses fermentasi dimana pekerja hanya bekerja untuk memisahkan VCO dengan blondo dan air, sisanya hanya menunggu. Untuk proses E dibutuhkan pekerja 2 orang untuk melakukan proses pengemasan.

\section{Desain lantai produksi dan simulasi}

Desain layout produksi VCO Desa Rejosari ditunjukkan pada Gambar 4 (i) dan (ii). Dalam penentuan layout produksi, terdapat beberapa pertimbangan di antaranya adalah layout diatur sedemikian rupa agar dapat menghasilkan jarak yang seminimal mungkin sehingga mampu 
meningkatkan efisiensi lantai produksi. Selain itu, layout dibuat sedemikian rupa sehingga mempermudah jalan keluar-masuk barang jadi ataupun barang setengah jadi (work in process). Penentuan koordinat tiap stasiun kerja dilakukan pada model simulasi dengan cara What-If Analysis, dan dipilih koordinat yang paling optimal dan dijadikan sebagai dasar penentuan layout lantai produksi.

Model simulasi yang sudah terverifikasi kemudian dijalankan (running) selama 4 bulan dengan jumlah replikasi 30. Hasil rata-rata output produksi kemudian dibandingkan dengan rata-rata utilisasi pekerjanya sebagaimana ditunjukkan pada Tabel 6. Hasil menunjukkan bahwa target output produksi telah tercapai dengan keputusan yang sudah dibuat yang berarti sudah efektif. Dilihat dari utilisasi pekerja, rata-rata utilisasi pekerja > $90 \%$ yang berarti sudah efisien. Oleh karena itu, dapat disimpulkan bahwa perancangan bisnis VCO pada aspek teknis telah tervalidasi dan dapat dieksekusi lebih lanjut.

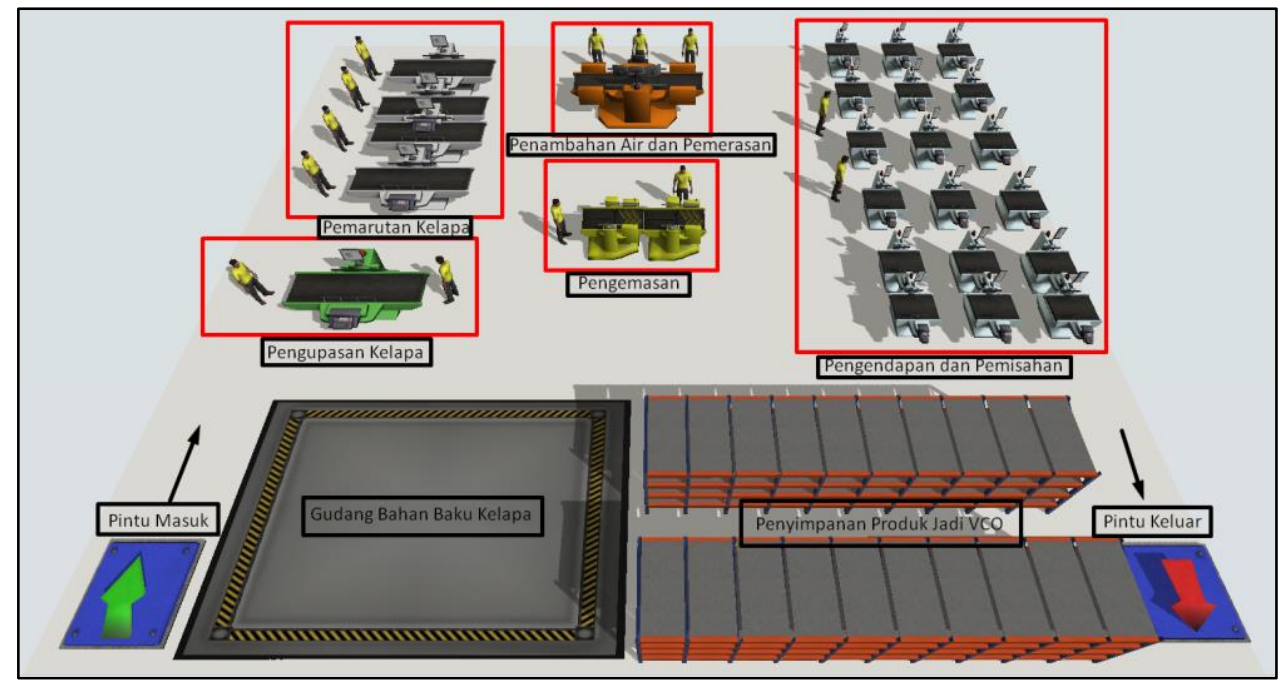

(i)

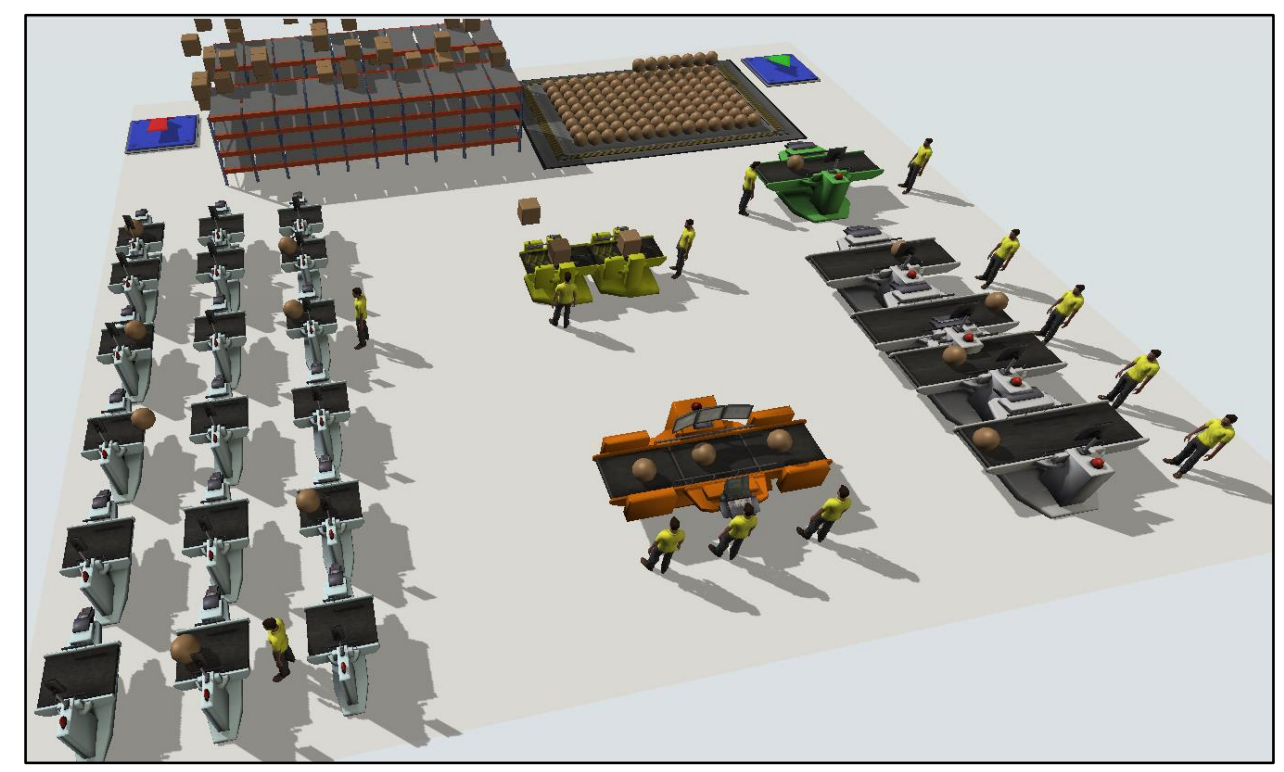

(ii)

Gambar 4. Desain layout dan simulasi produksi VCO Desa Rejosari 
Tabel 6. Hasil simulasi terhadap output produksi dan utilisasi pekerja

\begin{tabular}{ccc}
\hline Bulan & Rata-Rata Output Produksi & Rata-Rata Utilisasi Pekerja \\
\hline 1 & 3003 & $91,7 \%$ \\
\hline 2 & 3211 & $92,1 \%$ \\
\hline 3 & 3414 & $93,2 \%$ \\
\hline 4 & 3594 & $93,4 \%$ \\
\hline
\end{tabular}

\section{Penyuluhan}

Hasil analisis perencanaan produksi VCO kemudian dipaparkan melalui penyuluhan kepada warga Desa Rejosari. Penyuluhan ini sangat penting untuk menilai pemahaman warga terhadap produk VCO, rencana produksi, hingga disetujui kelayakannya. Gambar 5 menunjukkan proses penyuluhan dan Gambar 6 merupakan hasil uji coba produksi VCO.

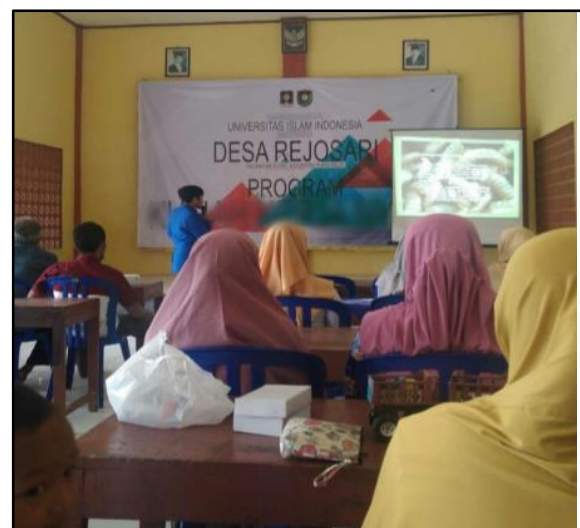

Gambar 5. Proses penyuluhan

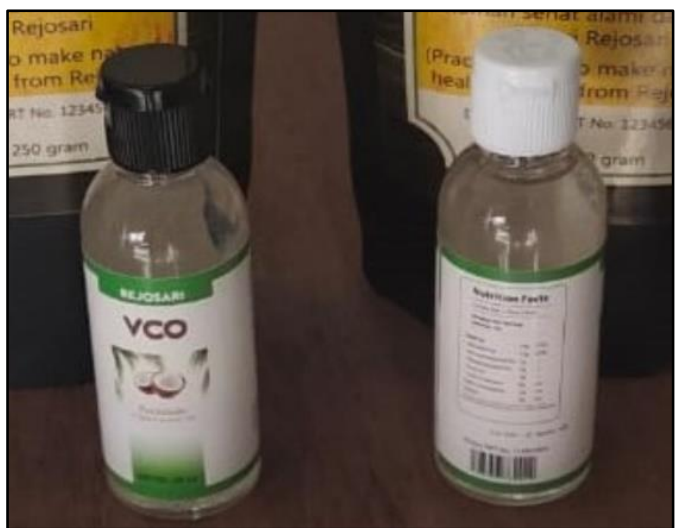

Gambar 6. VCO Desa Rejosari

\section{Kesimpulan}

Telah dihasilkan master plan yang fokus pada aspek teknis dari perancangan bisnis VCO di Desa Rejosari sebagai bentuk pengabdian masyarakat. Hasil pengabdian berupa keputusan lokasi yang layak untuk didirikan pabrik produksi VCO yaitu di samping SMK VIP Maarif NU 1 Kemiri. Untuk memenuhi permintaan-permintaan selama 4 bulan ke depan, diperlukan 2 orang pekerja dan 2 alat pengupas kelapa (golok), 4 pekerja dan 4 alat pemarut, 3 pekerja dan 3 alat peras (kain saring tahu), 148 ember titrasi di bulan pertama, 158 di bulan kedua, 168 di bulan ketiga, 173 di bulan keempat dengan 2 orang pekerjanya, dan 2 orang untuk melakukan proses pengemasan. Semua pekerja yang dibutuhkan akan direkrut dari warga Desa Rejosari itu sendiri dan peralatan yang dibutuhkan tidak memerlukan investasi yang besar karena dapat dengan mudah dibuat sendiri. Selain itu, telah dihasilkan rancangan layout dari lantai produksi VCO. Metode simulasi juga telah berhasil digunakan dalam memvalidasi perancangan bisnis pada aspek teknis khususnya proses produksi dan hasilnya telah mencapai target efektivitas dan efisiensi. 
Namun dalam pelaksanaan pengabdian ini terdapat beberapa ketidakpastian yang belum dipertimbangkan seperti ketersediaan material/kelapa dan kerusakan alat. Pada pengabdian masyakarat selanjutnya, setelah bisnis tersebut direalisasikan, dapat dianalisis lebih lanjut terkait ketersedian material dan frekuensi kerusakan alat yang terjadi di lantai produksi. Dengan dibangunnya bisnis VCO, Desa Rejosari dapat memaksimalkan penggunaan SDA kelapa yang tumbuh subur di Desa Rejosari, menambah lapangan pekerjaan bagi warga Desa, mengurangi dampak buruk lingkungan dari pembuangan waste kelapa yang berlebihan pasca panen, dan memberikan pendapatan lebih bagi Desa Rejosari dari hasil penjualan produk VCO.

\section{Ucapan Terima Kasih}

Terima kasih diucapkan kepada Desa Rejosari atas segala bentuk perhatian dan timbal balik yang penulis terima dan kawan peneliti dari Teknik Kimia, Universitas Islam Indonesia atas kerjasama dalam melakukan pengabdian masyarakat ini. Tidak lupa kepada revieweryang telah membuat tulisan ini menjadi lebih baik.

\section{Referensi}

Abidanish. (2010). Produk Olahan Hasil Kelapa Mengurai Manfaat Kelapa (Artikel Web). Diakses di https://produkkelapa.wordpress.com/2010/02/03/analisa-bisnis-minyak-goreng-kelapa-vco/. Diakses pada 12 Januari 2020.

Anwar, C., \& Salima, R. (2016). Perubahan Rendemen dan Mutu Virgin Coconut Oil (VCO) Pada Berbagai Kecepatan Putar Dan Lama Waktu Sentrifugasi. Jurnal Teknotan, 10(2), 51-60. Doi:10.24198/jt.vol10n2.8.

Arowoshegbe, A. O., \& Emmanuel, U. (2016). Sustainability and Triple Bottom Line: An Overview Of Two Interrelated Concepts. Igbinedion University Journal of Accounting, 2, 88-126.

Aziz, T., Olga, Y., \& Sari, A. P. (2017). Pembuatan Virgin Coconut Oil (VCO) Dengan Metode Penggaraman. Jurnal Teknik Kimia, 23(2), 129-136.

Bangkele, E. M., Antara, M. \& Damayanti, L. (2016). Cocoa Processing Industry Feasibility Analysis (Case Study in House of Chocolate Department of Industry Central Sulawesi Province) in Palu. The Agriculture Science Journal, 3(1), 57-70. DOI:10.22487/j24077593.2016.v3.i1.8126.

Barlina, R. \& Torar, D. (2008). Diversifikasi Produk Virgin Coconut Oil (VCO). Jurnal Litbang Pertanian, 21(1), 1-12. DOI: http://dx.doi.org/10.21082/bp.v0n35.2008.\%25p.

Elquliti, S. A. H, \& Elalem, A. G. (2018). Feasibility Study for Establishing A Restaurant in Jeddah. American Scientific Research Journal for Engineering, Technology, and Sciences, 40(1), 143167.

Herjanto, E. (2009). Sains Manajemen: Analisis Kuantitatif untuk Pengambilan Keputusan. Jakarta: Grasindo.

Jurnalis, A. (2019). Analisis Pengembangan Produksi Dan Pemasaran Santan Kelapa Murni Berbasis Data Pelanggan di PT. Inhil Sarimas Kelapa Sungai Sejuk Tembilahan Riau (Skripsi). Diakses di http://repository.uinjambi.ac.id/. Diakses pada 07 Juni 2021.

Kuncoro, A. W., Naryoto, P., \& Nugroho, S. Y. (2017). Sangrai Peanut Business Feasibility Analysis (Case Study of Keranggan Village, Setu, Tangerang Selatan, Banten). International Journal of Scientific Research in Science and Technology, 3(4), 24-28

Mohammed, S. R., Naji, H. I., \& Ali, R. H. (2019). Impact of The Feasibility Study on The Construction Projects. IOP Conf. Series: Materials Science and Engineering, 518(2), 1-9. DOI: 10.1088/1757$899 X / 518 / 2 / 022074$.

Rahman, S., Palenewen, V. V. J., Elly, F. H. (2016). Analisis Kelayakan Agroindustri Virgin Coconut Oil (Studi Kasus Kelompok Tani Anugrah Kelurahan Tandurusa Kecamatan Aertembaga Kota Bitung). Agri-SosioEkonomiUnsrat, 12(3A), $147-158$.

Saaty, T.L. (1980). The Analytic Hierarchy Process. New York: McGraw-Hill International. 
Transformasi: Jurnal Pengabdian Masyarakat, Vol. 17, No. 1, Juni 2021: 86-96

Saepudin, P., Putra, F. K. K., \& Adrian, G. A. W. (2019). Feasibility Study for a Full-Service Independent Hotel: a Case Study in Hotel X Bandung, Indonesia. Journal of Economics, Business, and Accountancy Ventura, 22(1), 59 - 71. DOI: http://dx.doi.org/10.14414/jebav.v22i1.1662.

Tarigan, U. P. P., Mardhatillah, A., Budiman, I., Sembiring, A.C., \& Ramadhan, M. S. (2019). Feasibility Study Analysis of Establishing Archery Sports Special Place. Journal of Physics: Conference Series, 10071), 1-6. DOI: 10.1088/1742-6596/1007/1/012027.

Umar, H. (2003). Studi Kelayakan Bisnis. Jakarta: Gramedia Pustaka Utama.

Wulandary, A., Fitriani, R., Mursalat, A., Darhyati, A. T., Masitah. (2020), Business Model Canvas: Implementasi Terhadap Industri Rumahan Produk Virgin Coconut Oil (VCO). Tangerang: Media Sains Indonesia. 